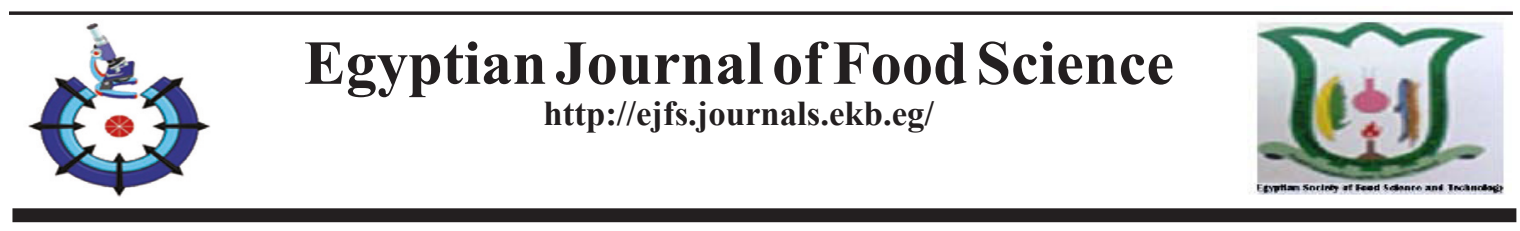

\title{
Public Health Risks and Microbial Contaminants Associated with Consumption of Local Fried Plantain (Dodo Ikire) in Osun State, Nigeria
}

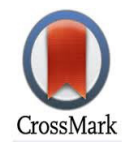

\author{
Wasiu O. Adebimpe ${ }^{*}$, Adeolu S.Oluremi ${ }^{2}$, Ayodeji O. Faremi ${ }^{3}$, Maryam A \\ Adebimpe ${ }^{4}$ \\ ${ }^{1}$ Department of Community Medicine, University of Medical Science, Ondo, Nigeria. \\ ${ }^{2}$ Department of Medical Laboratory Science, Ladoke Akintola University of \\ Technology, Ogbomoso, Nigeria. \\ ${ }^{3}$ Osun State Hospital Management Board, Nigeria. \\ ${ }^{4}$ Department of Medical Laboratory Sciences, Kwara State University Ilorin, Nigeria
}

\begin{abstract}
T OCALLY fried plantains (Dodo Ikire) which are local snacks for both indigenes and travelers are always packed inside a transparent nylon bag which may pose public health risks to consumers. Samples were collected from major production and hawking hotspots for microbiological analysis. This study aimed to isolate and determine microbial load of Dodo Ikire using standard microbiological procedures. Analysis of the fried plantain revealed total bacterial count ranging from $3.0 \times 10^{2} \mathrm{cfu} / \mathrm{ml}$ (Bacillus cereus) to $4.0 \times 10^{8} \mathrm{cfu} /$ $\mathrm{ml}$ (Staphylococcus aureus). Mean coliform count ranged from $2.6 \times 10^{6} \mathrm{cfu} / \mathrm{ml}$ (Klebsiella $s p p)$ to $6.0 \times 10^{3} \mathrm{cfu} / \mathrm{ml}$ (Escherichia coli), and fungal count ranged from $3.0 \times 10^{4} \mathrm{cfu} / \mathrm{ml}$ (Penicillium marneffei) to $3.0 \times 10^{8} \mathrm{cfu} / \mathrm{ml}$ (Yeast). The isolated microorganisms includes fungi, enterobactericae and gram positive bacteria. The coliform has the highest counts $\left(\geq 10^{2}\right)$ in most samples; this can be due to post production contamination as the entire food samples involved use of heat during manufacturing. This study concluded that fried plantain (Dodo Ikire) posed a risk to Nigerian people due to high microbial load and it is a read-made food that most travelers usually consume.
\end{abstract}

Keywords: Fried plantain, Microorganisms, Bacteria count, Food safety, Street foods.

\section{Introduction}

Plantain (Musa spp.), is a major starchy staples in the sub-Saharan Africa both for rural and urban populace, providing more than $25 \%$ of the carbohydrates and $10 \%$ of the daily calorie intake for more than 70 million people in the continent (IITA Annual report, 2000). Plantain cultivation is attractive to farmers due to low labor requirements for production compared with cassava, maize, rice and yam (Marriott and Lancaster, 2003). Therefore, It contributes significantly to food and income security of people engaged in its production and trade, particularly in developing countries. Plantain has diversity of minerals; it is high in potassium $(42 \mathrm{mg} / 100 \mathrm{~g})$, low in sodium $(17 \mathrm{mg} / 100 \mathrm{~g})$ and fat $(0.1 \%)$ making it suitable to control blood pressure (Mohapatra, Mishra and Sutar, 2010; Kanazawa and Sakakibara, 2000).
It is often recommended to be consumed by people who are intolerant to salt. Many nutritive minerals are essential to living organisms because they are use to activate hormone, enzymes, and other organic molecules that participate in the growth, function and maintenance of life processes (Adams and Moss, 2008). Minerals cannot be synthesized and must be provided from plants, vegetables or mineral rich water (Adewusi, Ojumu and Falade, 1999). Minerals are the catalysts, which create a healthy environment which body is using for vitamins, proteins, carbohydrates and fats. (Anwar and Bhanger, 2003). The consumption of plantain promote weight loss in obese individuals and caters to the calorific need of many developing countries (Mohapatra, Mishra and Sutar, 2010; Kanazawa and Sakakibara, 2000).

"Corresponding author: Email: lekanadebimpe@gmail.com

Received:20/9/2019; accepted:6/5/2020

DOI: 10.21608/EJFS.2020.16929.1019

C2020 National Information and Documentation Centre (NIDOC) 
Since the fried plantain is locally made, adequate hygiene and precaution will minimize the risks of contamination both from chemical, physical and biological agents (Abdalla, Suliman and Bakhiet, 2009). Dodo Ikire is a fast food being consumed by both indigene and traveler along Ife - Ibadan road in Nigeria. It is specifically being sold along the express highways and local markets. It is made by roasting ripe plantain spiced with local pepper in hot palm oil and then packaged in polythene or nylon bag. However these are preserved continuously for days until it is sold in the market, this can lead to biological contamination if not properly preserved.

Most fresh plantains are either taken raw or processed into various products at various stages of ripening (Akinyemi, Aiyelaagbe and Akyeampong, 2008) and plantains are usually transported from one village to urban. The natural ripening process is ideal; however, the use of growth hasteners in order to create a faster source of income is of high concerns (Agoreyo, Obuekwe and Edosomwan, 2003) Bananas and plantains (Musa species) are perennial and herbaceous plants. Keeping plantain in a jute bags instead could encourage growth of microorganisms (Ajao and Atere, 2009, Mokbell and Hashina, 2005). Many products such as: chips,flour, beer and beverage drink have been commercially produced from plantain fruits (Casimir and Jayaraman, 1971). A typical staple snack produced in some Western States of Nigeria is called 'Dodo ikire' which originated from Ikire Town in Osun State, Nigeria. There is dearth of information on the proximate, mineral composition and microbial counts of 'Dodo ikire' (over ripe fried plantain).

The plantain which is usually being produced from soft, overripe plantain has potential of being colonized by micro-organisms if not properly preserved by the food vendors or handlers. Recently, outbreaks of epidemic of diarrhea were reported in Ikire and her environs where locally fried plantain were predominantly being produced and consumed. This may be as a result of potential pathogens associated with stale 'dodo Ikire' which have not been studied. To avoid future calamity, this study aimed to assess microbial contaminants and load associated with the consumption of locally fried plantain in Ikire, Osun state, Southwestern Nigeria.

\section{Materials and Methods}

Study areas

The study areas were Ikire, Gbongan and Akoda towns. These are the major production and hawking sites for Dodo Ikire in southwestern Nigeria. While Ikire town is traditionally known for the production, parading numerous open local kitchen where it is been produced within the town, the nearby Gbogan community also got involved in processing and production but on a lower scale. The expressway road traversing the communities is the major hawking site where about thousand travelers purchased the products on a daily basis. While some eat it immediately or within the period of transportation, others do keep it and give to their loved ones when they get to their destination.

\section{Study design}

The study was a cross sectional study involving purchased of locally fried plantains from point of production and different hawking sites.

\section{Study population}

Dodo Ikire products collected from various production and selling points within Ikire and Gbongan communities of southwestern Nigeria.

\section{Sample location and collection}

Thirty six (36) locally fried plantains purchased from Ikire, Gbongan, and Akoda were packaged aseptically in a nylon exposed to ultraviolet ray and transported immediately at $-4^{0} \mathrm{C}$ to the laboratory for processing.

\section{Microbiological analysis}

Samples were first examined macroscopically for any form of growth. Viable microbial count was performed on collected samples as follows; a 10 -fold serial dilution of up to $10^{-10}$ for each sample was prepared in $0.1 \%$ peptone water. For viable bacterial count, each dilution was subsequently plated onto standard Mueller Hinton Agar (MHA oxoid product). The MHA plates were incubated at $37^{\circ} \mathrm{C}$ for $48 \mathrm{hrs}$. The colony forming units (CFU) were counted on plates having between 30 and 300 colonies (Barrow and Feltham,2004). The enumeration of viable bacteria count was carried out in duplicate on each sample and the isolated bacteria were identified using Analytical Profile Index API (Smith et al., 1972). For fungi count, 
Sabouraud Dextrose Agar (SDA) was used to plate the dilutions. The plates were incubated at room temperature in a moistened and dark environment for 3 to 5 days. The mean of colony forming unit per gram were calculated and recorded. Fungi isolates were further identified with Lactophenol blue solution in conjunction with mycology atlas (Monica Cheesbrough, 2012).

\section{Data Analysis}

Laboratory data generated were stored in the MS excel-2007 programme before exporting to

SPSS software for analysis. Descriptive analysis was performed to determine Total Viable Bacterial Count (TVBC), and a significant $p$ value was considered at 0.05 .

\section{Results}

A total of 36 Dodo Ikire samples, each comprising 5 balls of dodo were purchased from different production and purchasing points in Ikire, Gbongan, and Akoda area of Osun state as showed in Table 1. Almost equal number and type of Dodo Ikire were bought from 3 different areas covered. A total of 36 samples comprising $18(50 \%)$ from the production sites and other $18(50 \%)$ from selling or hawking sites were purchases.

\section{Bacteria Isolation}

All non-pepper dodo samples purchased at production point $\left(1 \mathrm{~A}_{1}, 2 \mathrm{~A}_{1}\right.$ and $\left.3 \mathrm{~A}_{1}\right)$ yield no bacteria. Aerobic spore bearer was isolated from all sample purchased from hawking sites. The most prevalent bacteria isolated include: Aerobic spore bearer (46.42\%), Bacillus spp (14.28\%) and Staphylococcus aureus (14.28\%) as shown in Table 2 . The least prevalence bacteria was Klebsiella spp, (3.57\%). Total bacteria counts for Staphylococcus aureus, Coagulase negative Staphylococcus sp and Escherichia coli ranged from $2.4 \times 10^{4}$ to $4.0 \times 10^{8} \mathrm{cfu} / \mathrm{ml}, 8.4 \times 10^{3}$ to $1.7 \mathrm{x}$ $10^{5} \mathrm{cfu} / \mathrm{ml}$ and $1.5 \times 10^{3} \mathrm{cfu} / \mathrm{ml}$ to $6.5 \times 10^{3} \mathrm{cfu} / \mathrm{ml}$ respectively. Staphylococcus aureus was the most prevalent isolated bacteria with average count of $3.0 \times 10^{2} \mathrm{cfu} / \mathrm{ml}$ and $1.47 \times 10^{7}$ in Ikire and Akoda community respectively. Table 2 and 3 showed the percentage and load of the isolated bacteria.

\section{Cultural and Morphological Characteristics of} the Fungi Isolated

Mould were the most isolated fungi from Dodo Ikire except three (3) specimens that yielded yeast cell, Pseudallescheria boydi and Penicillium marneffei with total count of $3.0 \mathrm{x}$ $10^{8} \mathrm{cfu} / \mathrm{ml}$ and $3.0 \mathrm{x} 14^{4} \mathrm{cfu} / \mathrm{ml}$, respectively. The fungal identified with lactophenol cotton blue preparation include Aspergillus spp, Rhizopus sp, Trycophyton verrucosumon, Microsporum canis, Exophala jeanselmei, Pseudallescheria boydi and Yeast cell Aspergillus spp and Rhizopus spp were the most predominant among the fungi isolates with prevalence of $22.2 \%$ each in Table 3 .

TABLE 1. Distribution of Dodo Ikire samples.

\begin{tabular}{|c|c|c|c|c|c|c|}
\hline Production $\mathbf{P}$ & $\begin{array}{c}\text { No } \\
\text { Pepper }\end{array}$ & $\begin{array}{c}\text { With } \\
\text { Pepper }\end{array}$ & Hawkiing $P$ & $\begin{array}{c}\text { No } \\
\text { Pepper }\end{array}$ & $\begin{array}{c}\text { With } \\
\text { Pepper }\end{array}$ & Total \\
\hline Ikire 1 & 1 & 1 & Ikire Flyover & 1 & 2 & 5 \\
\hline Ikire 2 & 1 & 2 & Ikire Bomb point & 2 & 1 & 6 \\
\hline Gbongan 1 & 1 & 1 & Gbongan Junctio & 2 & 1 & 5 \\
\hline Gbongan 2 & 2 & 1 & Gbongan municipal & 1 & 1 & 5 \\
\hline Akoda 1 & 1 & 2 & Akoda 1 & 1 & 1 & 5 \\
\hline
\end{tabular}


TABLE 2. Total count of bacteria and fungi isolated.

\begin{tabular}{|c|c|c|c|c|}
\hline DODO & BACTERIA & EOUAT (efurmt) & FUNGI (SBA OR LPB) & \\
\hline \multicolumn{5}{|l|}{ IKIRE } \\
\hline $1 \mathrm{~A}_{1}$ & Aerobic Spore Bearer & & Pseudallescheria boydi on SBA & $1.9 \times 10^{6}$ \\
\hline $1 \mathrm{~A}_{2}$ & Aerobic Spore Bearer & & Nil & \\
\hline $1 \mathrm{~A}_{3}$ & Staphylococcus aureus & $3.0 \times 10^{6}$ & Nil & \\
\hline $1 \mathrm{~B}_{1}$ & Bacillus cereus & $4.0 \times 10^{3}$ & $\begin{array}{l}\text { Yeast on SBA/ Aspergillus spp on } \\
\text { LPB }\end{array}$ & $3.0 \times 10^{8} / \mathrm{Nil}$ \\
\hline $1 \mathrm{~B}_{2}$ & Escherichia coli & $6.0 \times 10^{3}$ & Nil & \\
\hline $1 \mathrm{~B}_{3}$ & $\begin{array}{l}\text { Coagulase negative } \\
\text { Staphylococcus }\end{array}$ & $8.4 \times 10^{3}$ & Nil & \\
\hline $\mathrm{IC}_{1} / 1 \mathrm{C}_{2}$ & Nil & & Nil & \\
\hline $1 \mathrm{C}_{3}$ & $\begin{array}{l}\text { Aerobic Spore Bearer/ } \\
\text { Bacillus cereus }\end{array}$ & $\mathrm{Nil} / 1.4 \times 10^{3}$ & & \\
\hline $1 \mathrm{D}_{1}$ & Escherichia coli & $1.5 \times 10^{3}$ & Nil & \\
\hline $1 \mathrm{D}_{2}$ & Aerobic Spore Bearer & & Nil & \\
\hline $1 \mathrm{D}_{3}$ & Aerobic Spore Bearer & & Nil & \\
\hline \multicolumn{5}{|c|}{ GBONGAN } \\
\hline $2 \mathrm{~A}_{1,2,3}$ & Nil & Nil & Penicillium marneffei on SBA & $3.0 \times 10^{4}$ \\
\hline $2 \mathrm{~B}_{1,2}$ & Nil & Nil & Nil & \\
\hline $2 \mathrm{~B}_{3}$ & Aerobic Spore Bearer & & Exophala jeanselmeion LPB & \\
\hline $2 \mathrm{C}_{1}$ & Bacillus cereus & $3.0 \times 10^{2}$ & $\begin{array}{l}\text { Rhizopus sp/Aspergillus flavus on } \\
\text { LPB }\end{array}$ & \\
\hline $2 \mathrm{C}_{2}$ & Aerobic Spore Bearer & & Nil & \\
\hline $2 \mathrm{C}_{3}$ & Aerobic Spore Bearer & & Nil & \\
\hline \multicolumn{5}{|c|}{ AKODA } \\
\hline $3 \mathrm{~A}_{1}$ & Nil & & Nil & \\
\hline $3 \mathrm{~A}_{2}$ & Aerobic Spore Bearer & & Nil & \\
\hline $3 \mathrm{~A}_{3}$ & Aerobic Spore Bearer & & Nil & \\
\hline $3 \mathrm{~B}_{1}$ & Staphylococcus aureus & $2.2 \times 10^{4}$ & Microsporum canis on LPB & \\
\hline $3 \mathrm{~B}_{2}$ & Staphylococcus aureus & $3.8 \times 10^{6}$ & Nil & \\
\hline $3 \mathrm{~B}_{3}$ & Staphylococcus aureus & $4.0 \times 10^{8}$ & Nil & \\
\hline $3 \mathrm{C}_{1}$ & Aerobic Spore Bearer & & Rhizopus sp on LPB & \\
\hline $3 \mathrm{C}_{2}$ & Aerobic Spore Bearer & & Nil & \\
\hline $3 \mathrm{C}_{3}$ & $\begin{array}{l}\text { Aerobic Spore Bearer/ } \\
\text { Bacillus cereus }\end{array}$ & $\mathrm{Nil} / 1.4 \times 10^{4}$ & Trycophyton verrucosumon LPB & \\
\hline $3 \mathrm{D}_{1}$ & $\begin{array}{l}\text { Coagulase negative } \\
\text { Staphylococcus }\end{array}$ & $1.5 \times 10^{4}$ & Nil & \\
\hline $3 \mathrm{D}_{2}$ & $\begin{array}{l}\text { Coagulase negative } \\
\text { Staphylococcus }\end{array}$ & $1.7 \times 10^{5}$ & Nil & \\
\hline $3 \mathrm{D}_{3}$ & Klebsiella Spp & $2.6 \times 10^{6}$ & Nil & \\
\hline
\end{tabular}

Egypt. J. Food. 48, No.1 (2020) 
TABLE 3. Percentage of bacteria and fungi isolated.

\begin{tabular}{lcll}
\hline \multicolumn{1}{c}{ Bacterial } & Number (\%) & \multicolumn{1}{c}{ Fungi } & \multicolumn{1}{c}{ Number (\%) } \\
\hline Aerobic Spore Bearer & $13(46.42 \%)$ & Aspergillus spp & $2(22.2 \%)$ \\
Bacillus spp & $4(14.28 \%)$ & Rhizopus sp & $2(22.2 \%)$ \\
Staphylococcus aureus & $4(14.28 \%)$ & Trycophyton verrucosumon & $1(11.1 \%)$ \\
Coagulase Negative Staphlococcus & $3(10.71 \%)$ & Microsporum canis & $1(11.1 \%)$ \\
Escherichia coli & $2(7.14 \%)$ & Exophala jeanselmei & $1(11.1 \%)$ \\
Klebsiella spp & $1(3.57 \%)$ & Pseudallescheria boydi & $1(11.1 \%)$ \\
& & Yeast cell & $1(11.1 \%)$ \\
\hline
\end{tabular}

Keys

1 - Ikire, 2 - Gbongan, 3 - Akoda, A -Dodo at Production point without pepper, B - Dodo at production point with pepper, C - Dodo at hawking pont1 with pepper, D - Dodo at hawking point 2 with pepper ,Subscript 1- Very close hawking point to production point, Subscript 2- Close hawking point to production point, Subscript 3- Far hawking point to production point.

\section{Discussion}

Almost all Dodo Ikire samples without pepper $\left(1 \mathrm{~A}_{1}, 2 \mathrm{~A}_{1}\right.$ and $\left.3 \mathrm{~A}_{1}\right)$ added during purchased at point of production did not yield any significant bacteria as showed in Table 3.1a. This implies that most contamination is from post handling and hawking. This research revealed that Dodo Ikire is contaminated withy Gram positive bacteria, Gram negative bacteria and different fungi. This result is in agreement with the work reported by Ajao and Atere (2009) and Oranusi and Braide (2012) that foods/snacks sold along the high ways are contaminated with different harmful microorganism. Bacillus spp and Aerobic spore bearers has been found to be associated with septicemia, meningitis, Urinary Tract Infection, wound infection and gastro intestinal infection were found to be most prevalent among the isolated bacteria.

Bacillus cereus causes a rapid-onset emetic syndrome characterized and a slower-onset diarrheal syndrome (Gilbert et al., 2000). Bacillus species and aerobic spore bearer are ubiquitous and toxin-producer which can illness. Staphylococcus species do produces endotoxin which can causing vomiting and diarhoea, Iolation of this bacteria in Dodo Ikire may be from skin. It may also indicates poor hygienic conditions and contamination during manufacturing/handling.

The presence of Enterobactericae suggested fecal contamination. Escherichia coli is capable of producing toxin(s) and some have been associated with traveler's diarrhea, haemorrhagic colitis and haemolytic uraemic syndrome (Adams and Moss, 2008). Majority of Klebsiella infections are associated with hospitalization. As opportunistic pathogens, Klebsiella spp. primarily attack immuno compromised individuals who are hospitalized and suffer from severe underlying diseases such as diabetes mellitus or chronic pulmonary obstruction. Nosocomial Klebsiella infections are caused mainly by Klebsiella pneumoniae, the medically most important species of the genus.

The presence fungi in the Dodo Ikire is not surprising as they disperse in the form of spores which is abundant in the air and can be introduce through dust and soil (Amusan et al., 2010). Their presence in this snack is of serious public health concern because it is implicated with the mycotoxin production (Casimir and Jayaraman, 1971). Microbial guideline for cook food stipulated that "the plate count for coliforms must be less than $10 \mathrm{cfu} / \mathrm{ml}$ (Aslam, Hamill and Musher, 2005), the microbial load of the dodo ikire samples was higher than stipulated, hence their presence constituted a health risk. It can be adjudged that the dodo Ikire in most location at Ibadan- Ife expressway road as obtained in this study are not fit for consumption. The food contamination may have been due to unhygienic production, packaging and storage practices.

\section{Conclusion}

Most pathogens isolated from locally fried plantain are of soil and intestinal origin which are transmitted via fecal-oral route. These are common causes of diarrhoeal diseases with great potential for significant morbidity and mortality. Contamination may be from unhygienic preparation, handling, and storage practices. It is therefore recommended that every process involved in productions and packaging should be done under strict sanitary and hygienic conditions. Hygienic storage conditions of processed Dodo Ikire among producers and personal hygiene among travellers and the general population is hereby recommended and should be encouraged. 


\section{Acknowledgement}

We acknowledge the producers of plantain chips for giving us opportunity to assess the point of production. In addition, we also appreciate all technical staffs of the Department of Medical Laboratory Science, Ladoke Akintola University of technology, Ogbomoso, Mercyland Campus for their assistance.

\section{Conflict of Interests}

No conflict of interest to declare

\section{$\underline{\text { References }}$}

Abdalla, M.A.; Suliman, S.E. and Bakhiet, A.O. (2009) (2009). Food safety knowledge and practices of street foodvendors in Atbara City (Naher Elneel State Sudan). African Journal of Biotechnology, 8 (24), 6967-6971.

Adams M.R. and Moss M.O. (2008) Bacterial Agents of Foodborne Illness In Food Microbiology Third Edition. The Royal Society of Chemistry, Cambridge, UK, p. 182 -269.

Adewusi S.R., Ojumu T.V., Falade O.S. (1999) The effect of processing on total organic acids content and mineral availability of simulated cassavavegetable diets. Plant Foods for Human Nutrition (Formerly Qualitas Plantarum), 1; 53 (4), 367-80.

Agoreyo B.O., Obuekwe I.F., Edosomwan D.O. (2003) Biochemical and microbiological changes in plantain (Musa paradisiaca) at various stages of ripening. Discovery and Innovation, 15 (3/4), 1716.

Ajao A.T., Atere T.G. (2009) Bacteriological assessment and hygienic standard of food canteens in Kwara State Polytechnic, Ilorin, Nigeria. African Scientist Journal, 3 (10), 173-80.

Akinyemi S.O., Aiyelaagbe I.O., Akyeampong E. (2008) Plantain (Musa spp.) cultivation in Nigeria: a review of its production, marketing and research in the last two decades. InIV International Symposium on Banana: International Conference on Banana and Plantain in Africa: Harnessing International, 5, 211-218).

Amusan E., Oramadike C.E., Abraham-Olukayode A.O., Adejonwo O.A. (2010) Bacteriological quality of street vended smoked blue whiting (Micromesistus poutasou). Internet Journal of Food Safety, 12,122-6.

Anwar F., Bhanger M.I. (2003) Analytical characterization of Moringa oleifera seed oil grown in temperate regions of Pakistan. Journal of Agricultural and food Chemistry, 51 (22), 6558-63.

Aslam S., Hamill R.J., Musher D.M. (2005) Treatment of Clostridium difficile-associated disease: old therapies and new strategies. The Lancet Infectious Diseases, 30, 5 (9), 549-58

Barrow G.I., Feltham R.K.A. (1993) Characters of Gram-negative bacteria. In: Cowan and Steel Anual for Identification of Medical Bacteria, In: Microbial Contamination of Locally Produced Cheese and Determination of their Antimicrobial Potential in Nigeria. $3^{\text {rd }}$ edition, Cambridge University Press pp. 94-149 (PDF)

Casimir D.J., Jayaraman K.S. (1971) Banana drink; a new canned product. Food Preserv Quart.

Gilbert R.J., De Louvois J., Donovan T., Little C., Nye K., Ribeiro C.D. (2000) Guidelines for the microbiological quality of some ready-toeat foods sampled at the point of sale. PHLS Advisory Committee for Food and Dairy Products. Communicable Disease and Public Health, 3 (3), 163-7.

IITA Annual report (2000) Project 2, Improving Plantain and Banana based systems.

Kanazawa K. and Sakakibara H. (2000) High content of dopamine, a strong antioxidant, in cavendish banana. Journal of Agricultural and Food Chemistry, 20; 48 (3), 844-8.

Marriott J., Lancaster P.A. (2003) Bananas and plantains. Handbook of tropical foods, 85-143.

Mohapatra, D., Mishra S. and Sutar N. (2010) Banana and its by-product utilization: an overview. 2010 .

Mokbel M.S., Hashinaga F. (2005) Antibacterial and antioxidant activities of banana (Musa, AAA cv. Cavendish) fruits peel. American Journal of Biochemistry and Biotechnology, 1 (3), 125-31.

Oranusi S.U., Braide W. (2012) Microbiological Safety Assessment of Apple Fruits (Malus domestica Borkh) Sold in Owerri Imo State Nigeria. Advance Journal of Food Science and Technology, 4 (2), 97-102.

Smith P.B., Tomfohrde K.M., Rhoden D.L., Balows A. (1972). API System: a Multitube Micromethod for Identification of Enterobacteriaceae, Appl Microbiol, 24 (3), 449-52. 